\title{
Kandungan Lignin, Selulosa dan Bahan Ekstrak Tanpa Nitrogen L.Minor Hasil Fermentasi Menggunakan Trichoderma harzianum dan Saccharomyces cerevisiae
}

\author{
H. Setiyatwan ${ }^{1 \mathbf{a}}$, E. Harlia ${ }^{1}$, D. Rusmana ${ }^{1}$ \\ ${ }^{I}$ Fakultas Peternakan, Universitas Padjadjaran, Jl. Raya Bandung-Sumedang KM. 21, 45363, Sumedang, \\ Indonesia, Phone:+6222 7798241, Fax: +6222 7798212 \\ aemail: hendisetiyatwan@gmail.com
}

\begin{abstract}
Abstrak
Latar Belakang dan Tujuan: L. minor telah digunakan sebagai pakan ternak, mengandung nutrient sangat lengkap yaitu protein kasar $(22,4 \%)$, asam amino lisin $(6,9 \%)$, metionin $(1,4 \%)$, dan histidin $(2,7 \%)$ tetapi kandungan serat kasar $(10,16 \%)$ dan lignin $(17,98 \%)$ tinggi. Penggunaan L. minor pada unggas dibatasi hingga 5\%. Tujuan dari penelitian ini adalah untuk mendapatkan kandungan lignin, selulosa paling rendah dan bahan ekstrak tanpa nitrogen paling tinggi L. minor hasil fermentasi dengan menggunakan Trichoderma harzianum (Th) dan Saccharomyces cerevisiae (Sc). Bahan dan Metode: Fermentasi L. minor dibagi menjadi dua tahap: I. Th $\left(3 \times 10^{7}\right.$ spora / 100 gram substrat $)$ dengan menambahkan $\mathrm{ZnCO}_{3}(186 \mathrm{ppm})$ dan dl-methionine $(286 \mathrm{ppm})$; II. Sc $\left(3 \times 10^{7}\right.$ spora / 100 gram substrat). Rancangan percobaan yang digunakan adalah rancangan acak lengkap (RAL) dengan 20 unit percobaan. Perlakuan terdiri atas P1 (Fermentasi menggunakan Th selama 1 hari dilanjutkan dengan Sc selama 9 hari), P2 (Th selama 3 hari dilanjutkan dengan Sc selama 7 hari), P3 (Th selama 5 hari dilanjutkan dengan Sc selama 5 hari), P4 ( Th selama 7 hari dilanjutkan dengan Sc selama 3 hari), P5 (Th selama 9 hari dilanjutkan dengan Sc selama 1 hari) diulang empat kali. Pengaruh perlakuan dianalisis dengan analisis varian dan dilanjutkan dengan uji Duncan untuk mengetahui perbedaan antara perlakuan. Hasil: Fermentasi menggunakan Th dan Sc memiliki efek yang signifikan $(\mathrm{P}<0,05)$ pada kandungan lignin, selulosa dan bahan ekstrak tanpa nitrogen. Waktu fermentasi paling baik adalah fermentasi dengan menggunakan Th selama 3 hari dan Sc selama 7 hari (P2) yang meningkatkan BETN $(34,42 \%)$, dan menurunkan Lignin(1,25\%) dan Selulosa (10,62\%). Kesimpulan: Fermentasi L. minor dengan kombinasi Th selama 3 hari dan Sc selama 7 hari dengan menambahkan dl-methionine dan $\mathrm{Zn}$ telah menghasilkan BETN tertinggi, kandungan lignin dan selulosa terendah.
\end{abstract}

Kata kunci: Kualitas nutrien L. minor, itik, fermentasi, Trichoderma harzianum, Saccharomyces cerevisiae.

\section{(Lignin, Selulos and Non Nitrogen Free Extract L.Minor Fermentation Using Trichoderma harzianum AND Saccharomyces cerevisiae)}

\begin{abstract}
Background and Objectives: L. minor has been used as animal feed, which contains high nutrition, i.e. Crude protein (22,4\%), amino acids lysin (6,9\%), methionin (1,4\%), and hystidin (2,7\%), but high crude fiber $(10,16 \%)$ dan lignin $(17,98 \%)$. Provision L. minor in poultry is limited to $5 \%$. Therefore, the objective of the study is to get the best quality of L. minor nutrient through fermentation process by using Trichoderma harzianum (Th) and Saccharomyces cerevisiae (Sc). Materials and Methods: L. minor fermentation is divided into two stages: 1.Th (3 $\times 10^{7}$ spores $/ 100$ grams substrate) with added $\mathrm{ZnCO}_{3}$ (186 ppm) and dl-methionine (286 ppm), II. Sc (3 $\times 10^{7}$ spores $/ 100$ grams of a substrate). Completed randomized design (CRD) was used in experimental design with 20 experimental units. The treatments consist of P1 (Fermentation using Th for 1 day continued with Sc for 9 days), P2 (Th for 3 days continued with Sc for 7 days), P3 (Th for 5 days continued with Sc for 5 days), P4 (Th for 7 days continued with Sc for 3 days), P5 (Th for 9 days continued with Sc for 1 day) with four replications. Analysis of variance was conducted to know the treatment effect. It was then followed by the Duncan test to know the difference between treatments. Results: Fermentation using Th and Sc has a significant
\end{abstract}


effect $(P<0.05)$ on lignin, selulos and non nitrogen free extract. The best duration of fermentation is Th for 3 days and Sc for 7 days (P2) that increasing non nitrogen free extract (34,42\%), and decreasing lignin (1,25\%) and selulosa (10,62\%). Conclusion: L. minor fermentation with the combination of Th for 3 days and Sc for 7 days with added dl-methionine and $\mathrm{Zn}$ has yielded the highest non nitrogen free extract, and the lowest lignin and selulosa contents.

\section{Keywords: Duckweed nutrient quality, fermentation, Trichoderma harzianum, Saccharomyces} cerevisiae.

\section{Pendahuluan}

Penyediaan bahan pakan masa depan akan tertuju pada bahan pakan alternatif terbarukan, ramah lingkungan, dan efisien. Bahan pakan demikian berasal dari limbah pertanian, by produk, west produk dan gulma air. Bahan baku asal gulma air secara kuantitas ketersediannya melimpah, mudah didapat dan harganya murah sehingga memungkinkan untuk dikembangkan. Salah satu gulma yang potensial untuk dikembangkan adalah Lemna minor (L. minor).

L. minor merupakan gulma perairan yang hidup dipermukaan air dengan periode pertumbuhan yang panjang (Xu et al., 2011). Perkembangannya sangat cepat dan menutupi seluruhan permukan air. Tumbuh baik di pinggir sawah, tambak, dan selokan. Kandungan karbohidrat $40-50 \%$, lipid 3-7\% dan abu 24\% (Gwaze and Mwale, 2015; Zhao et al., 2014). L. minor yang dibudidayakan dengan pemupukan intensif menghasilkan produksi biomassa sebanyak 1,76-2,34\%. Kandungan nutrient sangat lengkap yaitu protein kasar $(22,4 \%)$, serat kasar $(10,16 \%)$, asam amino lisin $(6,9 \%)$, metionin $(1,4 \%)$, dan histidin (2,7\%) (Akter.,et.al. 2011), akan tetapi penggunaan dalam ransum unggas terbatas sampai tingkat 5\%. Hal demikian disebabkan karena kandungan lignin $(17,98 \%)$, selulosa $(15,79 \%)$ dan hemiselulosa $(24,65 \%)$ yang sangat tinggi (Arif et al., 2018). Fermentasi merupakan salah satu cara untuk mengatasi keterbatasan penggunaan.

Fermentasi adalah pengolahan pakan secara biologi menggunakan mikroba baik bakteri maupun jamur (Parisutham et al., 2014; Wan and Li., 2012). Enzim yang dihasilkan mikroba merupakan penentu keberhasilan pengolahan. Fermentasi dapat meningkatkan ketersediaan nutrien dan mengurangi antinutrisi (Haustetn, et.al., 1990). Pemecahan fraksi serat kasar yaitu selulosa, lignin, dan hemiselulosa menjadi monomer dapat dilakukan dengan menggunakan Trichoderma harzianum.
Trichoderma harzianum merupakan mikroba yang sangat efektif dalam menurunkan kandungan serat kasar tepung inti sawit

(Ginting dan Krisnan. 2006). Kandungan serat kasar $L$. minor menurun sebesar 76,06\% setelah difermentasi dengan Trichoderma harzianum selama 6 - 9 hari (Setiyatwan.2007). Penurunan kandungan serat kasar pada substrat hasil fermentasi tidak diikuti oleh peningkatan kandungan nutrient. Bahan pakan asal gulma hasil fermentasi memiliki keterbatasan penyediaan asam amino dan mineral $\mathrm{Zn}$ sehingga perlu ditambahkan dari luar. Penambahan dalam bentuk anorganik memiliki keterbatasan ketersediaan dibandingkan dengan bentuk organik. Bentuk organik memiliki nilai kecernaan yang tinggi. Perubahan demikian dapat dilakukan dengan fermentasi menggunakan ragi.

Saccharomyces cerevisiae adalah ragi yang dapat menghasilkan protein heterolog, memperkaya asam amino metionin, dan $\mathrm{Zn}$ dalam bentuk organik. $\mathrm{Zn}$ terlibat dalam struktur dan fungsi protein dan asam nukleat (Hensing et.al. 1995). Saccharomyces cerevisiae dapat menggabungkan ion $\mathrm{Zn}$ dengan protein. Proses fermentasi oleh Trichoderma harzianum dan dilanjutkan Saccharomyces cerevisiae akan meningkatkan kualitas L. minor. Jalur metabolisme sekunder dari kedua mikroba bersifat sinergis.

Trichoderma harzianum dapat memberikan nitrogen untuk pertumbuhan Saccharomyces cerevisiae dan kemudian digunakan sebagai bahan baku untuk pembentukan ikatan logam dan asam amino. Aktivitas kedua mikroba (co-culture) menghasilkan enzim komplementer sebagai ekspresi mutual jalur metabolik pemanfaatan substrat. Penelitian tentang peningkatan kualitas L. minor melalui fermentasi demikian belum dilakukan. Oleh karena itu, tujuan dari penelitian ini adalah untuk menentukan kandungan lignin, selulosa paling rendah dan bahan ekstrak tanpa nitrogen paling tinggi $L$. minor hasil fermentasi berdasarkan dua jenis mikroba. 


\section{Materi dan Metode}

\section{Bahan dan Alat Penelitian}

Bahan penelitian terdiri atas L. minor, potato dextrose, PDA agar, Aquadest, $\mathrm{ZnCO}_{3}$, dl-mehionin, beras, tripton, kapas, Trichoderma harzianum, dan Saccharomyces cerevisiae. Peralatan terdiri atas timbangan analitik, timbangan teknis, labu ukur $1000 \mathrm{ml}$, erlenmeyer $1000 \mathrm{ml}$, cangkir pengaduk, tabung reaksi, jarum oase, lampu spirtus, gelas erlenmeyer, sterilisator, gelas ukur, kertas etiket, oven listrik, kulkas, autoklaf, dan fermentor.

\section{Prosedur Penelitian}

Substrat terdiri atas campuran L. minor dan medium selektif. Campuran dikukus selama 60 menit pada suhu $115^{\circ} \mathrm{C}$ dan tekanan 1,1 atmosfer. Mikroba Trichoderma harzianum diinkubasi dalam setiap perlakuan sebanyak $3 \mathrm{x}$ $10^{7}$ spora/100 gram substrat selama $1,3,5,7$, dan 9 hari pada suhu kamar. Setelah fermentasi tahap pertama, ditambahkan $\mathrm{ZnCO}_{3}(186 \mathrm{ppm})$ dan dl-methionine (286 ppm). Selanjutnya, masing-masing substrat difermentasi menggunakan Saccharomyces cerevisiae sebanyak $3 \times 10^{7}$ spora/100 gram substrat selama 9, 7, 5, 3, dan 1 hari. Setelah fermentasi, produk dikeringkan dengan oven.

\section{Rancangan Percobaan}

Rancangan percobaan menggunakan rancangan acak lengkap (RAL) untuk lima perlakuan dengan total 20 unit percobaan. Perlakuan terdiri atas P1 (Fermentasi menggunakan Trichoderma harzianum selama 1 hari dilanjutkan dengan Saccharomyces cerevisiae selama 9 hari), P2 (Trichoderma harzianum selama 3 hari dilanjutkan dengan Saccharomyces cerevisiae selama 7 hari), P3 (Trichoderma harzianum selama 5 hari dilanjutkan dengan Saccharomyces cerevisiae untuk 5 hari), P4 (Trichoderma harzianum selama 7 hari dilanjutkan dengan Saccharomyces cerevisiae selama 3 hari), P5 (Trichoderma harzianum selama 9 hari dilanjutkan dengan Saccharomyces cerevisiae selama 1 hari) dengan empat ulangan.

\section{Peubah yang diamati}

\section{(i) Bahan Ekstrak Tanpa Nitrogen}

Kandungan BETN ditentukan berdasarkan perhitungan : 100-(Abu+Protein Kasar+Serat Kasar+Ekstrak Eter)

\section{(ii) Lignin}

Analisis Kandungan lignin dengan metode Datta yang dikemukakan oleh Chesson
(1981). Penetapan lignin dengan metoda analisis asam sulfat $72 \%$

\section{(iii) Selulosa}

Analisis Kandungan Selulosa dengan metode Datta yang dikemukakan oleh Chesson (1981). Penetapan selulosa dengan metoda analisis asam sulfat $72 \%$.

\section{Analisis Statistik}

Data yang diperoleh dianalisis dengan analisis varian satu arah (ANOVA) (Steel dan Torrie, 1991). Perbedaan antar perlakuan di uji dengan menggunakan uji jarak berganda Duncan dengan tingkat signifikasi 5\% .

\section{Hasil dan Pembahasan}

\section{Pengaruh Perlakuan terhadap Kandungan Bahan Ekstrak Tanpa Nitrogen}

Bahan ekstrak tanpa nitrogen (BETN) merupakan karbohidrat yang meliputi monosakarida, disakarida dan polisakarida yang mudah larut dalam larutan asam dan basa serta memiliki daya cerna yang tinggi (Anggorodi, 1994). Rataan kandungan bahan ekstrak tanpa nitrogen L. minor hasil biofermentasi dengan mengunakan Trichoderma harzianum yang dilanjutkan Saccharomyces cerevisiae dicantumkan pada Tabel 1.

Tabel. 1 menunjukkan bahwa rataan kandungan bahan ekstrak tanpa nitrogen $L$. minor hasil fermentasi dengan menggunakan Trichoderma harzianum yang dilanjutkan Saccharomyces cerevisiae yang paling tinggi sampai dengan yang paling rendah secara berurutan adalah P2 (37,23\%), P3 (37,03\%), P5 $(35,39 \%)$, P4 (34,42\%) dan P1 (27,92\%).

Pengaruh perlakuan terhadap rataan kandungan bahan ekstrak tanpa nitrogen $L$. minor hasil biofermentasi dapat diketahui dengan melakukan analisis statistik. Hasil analisis sidik ragam menunjukkan bahwa biofermentasi dengan menggunakan Trichoderma harzianum yang dilanjutkan Saccharomyces cerevisiae nyata $(\mathrm{P}<0,05)$ meningkatkan kandungan bahan ekstrak tanpa nitrogen L. minor. Hasil uji jarak berganda Duncan menunjukkan bahwa rataan kandungan bahan ekstrak tanpa nitrogen L. minor. hasil fermentasi dengan menggunakan Trichoderma harzianum selama satu hari yang dilanjutkan Saccharomyces cerevisiae selama sembilan hari (P1), berbeda nyata dibandingkan dengan kandungan BETN L. minor hasil fermentasi dengan menggunakan Trichoderma harzianum selama tiga, lima, tujuh dan sembilan hari yang 
dilanjutkan Saccharomyces cerevisiae selama tujuh, lima, tiga, dan satu hari (P2), (P3), (P4) dan(P5). Peningkatan kandungan bahan ekstrak tanpa nitrogen duckweed disebabkan karena kedua mikroba yang digunakan untuk fermentasi menurunkan kandungan serat kasar dan abu sehingga kandungan BETN dalam substrat meningkat.

Fermentasi dengan menggunakan Trichoderma harzianum selama tiga hari yang dilanjutkan Saccharomyces cerevisiae selama tujuh hari (P2) merupakan perlakuan yang paling baik. Kandungan BETN meningkat dari $33,61 \%$ sebelum dilakukan fermentasi menjadi $37,23 \%$. Hal demikian menunjukkan meningkatnya kandungan karbohidrat yang terdiri atas monosakarida, disakarida dan polisakarida mudah larut dalam larutan asam dan basa.

\section{Pengaruh Perlakuan terhadap Kandungan Lignin}

Rataan kandungan lignin L. minor hasil fermentasi dengan mengunakan Trichoderma harzianum yang dilanjutkan Saccharomyces cerevisiae dicantumkan pada Tabel 1. Rataan kandungan lignin L. minor hasil fermentasi dengan menggunakan Trichoderma harzianum yang dilanjutkan Saccharomyces cerevisiae yang paling tinggi sampai dengan yang paling rendah secara berurutan adalah $\mathrm{P} 1(9,78 \%)$, $\mathrm{P} 5(8,12 \%), \mathrm{P} 3(6,08 \%), \mathrm{P} 4(5,08 \%)$ dan $\mathrm{P} 2$ $(1,25 \%)$.

Hasil analisis sidik ragam pengaruh perlakuan terhadap rataan kandungan lignin $L$. minor hasil fermentasi dengan menggunakan Trichoderma harzianum yang dilanjutkan Saccharomyces cerevisiae nyata $(\mathrm{P}<0,05)$ mempengaruhi kandungan lignin. Perbedaan antar perlakuan diuji dengan menggunakan uji jarak berganda Duncan. Rataan kandungan lignin L. minor hasil fermentasi dengan menggunakan Trichoderma harzianum selama satu hari yang dilanjutkan Saccharomyces cerevisiae selama sembilan hari (P1), berbeda nyata dibandingkan dengan kandungan lignin L. minor hasil fermentasi dengan menggunakan Trichoderma harzianum selama tiga, lima, tujuh dan sembilan hari yang dilanjutkan Saccharomyces cerevisiae selama tujuh, lima, tiga, dan satu hari (P2), (P3), (P4) dan(P5).

Kandungan lignin L. minor hasil fermentasi dengan menggunakan Trichoderma harzianum selama tiga hari yang dilanjutkan Saccharomyces cerevisiae selama tujuh hari (P2) memiliki kandungan lignin paling rendah. Fermentasi dengan menggunakan Trichoderma harzianum selama tiga hari telah cukup untuk mendegradasi kandungan lignin substrat. Apabila lama fermentasi semakin lama maka akan terjadi peningkatan kadungan serat kasar yang berasal dari khitin asal massa mikroba. Lama waktu fermentasi selama tujuh hari dengan menggunakan Saccharomyces cerevisiae merupakan waktu yang paling baik untuk menurunkan kandungan lignin. Waktu fermentasi yang semakin lama akan menyebabkan terjadinya peningkatan kandungan serat kasar pada substrat. Hal demikian disebabkan oleh menurunnya kandungan air substrat dan meningkatnya jumlah dinding sel asal kapang.

\section{Pengaruh Perlakuan terhadap Kandungan Selulosa Duckweed}

Rataan kandungan selulosa $L$. minor hasil fermentasi dengan menggunakan Trichoderma harzianum yang dilanjutkan Saccharomyces cerevisiae dicantumkan pada Tabel 1. Rataan kandungan selulosa L. minor hasil fermentasi dengan menggunakan Trichoderma harzianum yang dilanjutkan Saccharomyces cerevisiae yang paling tinggi sampai dengan yang paling rendah secara berurutan adalah $\mathrm{P} 1(21,78 \%), \mathrm{P} 5(17,98 \%)$, P3(16,19\%), P4(14,76\%) dan P2 (10,62\%)

Hasil analisis sidik ragam pengaruh perlakuan terhadap rataan kandungan selulosa L. minor hasil fermentasi menggunakan Trichoderma harzianum yang dilanjutkan Saccharomyces cerevisiae nyata $(\mathrm{P}<0,05)$ mempengaruhi kandungan selulosa. Perbedaan antar perlakuan diuji dengan menggunakan uji jarak berganda Duncan.

Rataan kandungan selulosa L. minor hasil fermentasi dengan menggunakan Trichoderma harzianum selama lima hari yang dilanjutkan Saccharomyces cerevisiae selama lima hari (P3), tidak berbeda nyata dibandingkan dengan kandungan selulosa L. minor hasil fermentasi dengan menggunakan Trichoderma harzianum selama tujuh hari yang dilanjutkan Saccharomyces cerevisiae selama tiga hari (P4). 
Table 1. Bahan Ekstrak Tanpa Nitrogen, Lignin, dan Selulosa L. minor Hasil Fermentasi dengan Menggunakan Trichoderma harzianum dan Saccharomyces cerevisiae

\begin{tabular}{lrrrrr}
\hline & \multicolumn{5}{c}{ Perlakuan } \\
\cline { 2 - 6 } Parameter & \multicolumn{1}{c}{ P1 } & \multicolumn{1}{c}{ P2 } & \multicolumn{1}{c}{ P3 } & \multicolumn{1}{c}{ P5 } \\
\hline BETN (\%) & $27,92 \pm 0,84^{\mathrm{a}}$ & $37,23 \pm 0,83^{\mathrm{c}}$ & $37,03 \pm 0,80^{\mathrm{c}}$ & $34,42 \pm 0,54^{\mathrm{b}}$ & $35,39 \pm 1,55^{\mathrm{bc}}$ \\
Lignin (\%) & $9,78 \pm 0,83^{\mathrm{e}}$ & $1,25 \pm 0,03^{\mathrm{a}}$ & $6,08 \pm 0,81^{\mathrm{c}}$ & $5,08 \pm 0,82^{\mathrm{b}}$ & $8,12 \pm 0,05^{\mathrm{d}}$ \\
Selulosa (\%) & $21,78 \pm 1,64^{\mathrm{d}}$ & $10,62 \pm 0,83^{\mathrm{a}}$ & $16,19 \pm 0,82^{\mathrm{bc}}$ & $14,76 \pm 0,80^{\mathrm{b}}$ & $17,98 \pm 0,82^{\mathrm{c}}$ \\
\hline
\end{tabular}

Huruf yang berbeda pada kolom signifikansi menunjukkan perbedaan nyata $(\mathrm{P}<0,05)$,

P1: Fermentasi menggunakan Trichoderma harzianum (Th) satu hari dan dilanjutkan dengan Saccharomyces cerevisiae (Sc) 9 hari, P2: Th 3 hari dilanjutkan Sc 7 hari, P3: Th 5 hari dilanjutkan Sc 5 hari, P4: Th 7 hari dilanjutkan Sc 3 hari, P5: Th 9 hari dilanjutkan Sc 1 hari.

tidak berbeda nyata dibandingkan dengan kandungan selulosa L. minor hasil fermentasi dengan menggunakan Trichoderma harzianum selama sembilan hari yang dilanjutkan Saccharomyces cerevisiae selama satu hari (P5). Berbeda nyata lebih rendah dibandingkan dengan kandungan selulosa L. minor hasil fermentasi dengan menggunakan Trichoderma harzianum selama satu hari yang dilanjutkan Saccharomyces cerevisiae selama sembilan hari (P1) dan nyata lebih tinggi dibandingkan dengan kandungan selulosa $L$. minor hasil fermentasi dengan menggunakan Trichoderma harzianum tiga hari yang dilanjutkan Saccharomyces cerevisiae selama tujuh hari (P2).

Rataan kandungan selulosa L. minor hasil fermentasi dengan menggunakan Trichoderma harzianum selama tiga hari yang dilanjutkan Saccharomyces cerevisiae selama tujuh hari (P2), merupakan perlakuan paling baik dalam menurunkan kandungan selulosa L. minor. Fardiaz (1988) menyatakan bahwa selulosa dapat dihidrolisis secara kimia atau enzimatik. Enari (1983) menyatakan bahwa mekanisme hidrolisis selulosa secara enzimatis dapat dibagi menjadi dua tahap yaitu tahap aktivasi oleh enzim $\mathrm{C} 1$ (ekso- $\beta-1.4$ glukanase atau selulase) dilanjutkan dengan tahap hidrolisis oleh enzim Cx (endo- $\beta-1.4$ glukanase) dan $\beta$ glukosidase selanjutnya pada proses fermentasi glukosa akan terbentuk asam piruvat (Fardiaz, 1988).

\section{Kesimpulan}

Fermentasi dengan kombinasi Trichoderma harzianum selama tiga hari dan dilanjutkan dengan Saccharomyces cerevisiae selama tujuh hari yang dilengkapi dengan asam amino dl-metionin dan $\mathrm{Zn}$ merupakan perlakuan paling baik. Hal demikian ditunjukkan oleh meningkatnya kandungan
Bahan Ekstrak Tanpa Nitrogen (37,23\%), menurunnya kandungan Lignin $(1,25 \%)$ dan selulosa $(10,62 \%)$.

\section{Ucapan Terimakasih}

Penulis mengucapkan terima kasih kepada Rektor Universitas Padjadjaran dan Kementerian Riset, Teknologi, dan Pendidikan Tinggi Universitas Padjadjaran yang telah mendukung penelitian ini. Penelitian dapat dilakukan dengan dukungan keuangan dari DIPA Fund Universitas Padjadjaran no. 855 / UN6.3.1 / PL / 2017 tertanggal 8 Maret 2017.

\section{Daftar Pustaka}

Akter, M., Chowdhury, S.D., Akter Y., and Khatun M.A., 2011. Effect of duckweed (Lemna sp. minor) meal in the diet of mial in the diet of laying Hen and their performances. Banglades Res, Pub. J. 5(3):252-261.

Arif,A.R., Andi, E, E., Hasnah, N., Ilham, H., Maudy,A,A. 2018. Optimasi Pretreatment melalui Metode Hydrothermal Pressure dan Pelarut Alkali pada Produksi Bioetanol dari Lemna minor. ALCHEMY Jurnal Penelitian Kimia, Vol. 14(1) 2018, 95106.

Anggorodi, R. 1984. Ilmu Makanan Ternak Umum. PT Gramedia.

Chesson, A. 1981. Effects of sodium hydroxide on cereal straws in relation to the enhanced degradation of of structural polysaccharides by rumen microorganisms. Journal Of The Science Food And Agriculture, Vol(32), Issue 8, 745-758.

Enari, T.M. (1983). Microbial Cellulase. New York: Applied Science Publisher. 
Fardiaz, S. (1992). Mikrobiologi Pangan I. Jakarta: PT. Gramedia Pustaka Utama.

Gwaze, F. R. and M. Mwale, 2015. The Prospect of Duckweed in Pig Nutrition: A Review. Journal of Agricultural Science., 7: 189 . DOI: http://dx.doi.org/10.5539/jas.v7n11p189

Ginting, S. P. and Krisnan, R., 2006. The Effect of fermentation using several strains of trichoderma and different incubation period to the chemical composition of palm kernel. Livestock research center Indonesia, 5-6 September 2016. Ministry of Agriculture Indonesia., pp: 944.

Haustetn, A. T., Gilman, R. H., Skillicorn, P. W., Vergara, V., Guevara, V., and Gastanaduy, A., 1990. Duckweed, a useful strategy for feeding chickens: performance of layers fed with sewagegrown Lemnacea species. Poultry

Steel, R.G.D. and Torrie, J.H., 1991. Principles and Procedures of Statistics, A Biometric Approach. $2^{\text {nd }}$ Ed. Translation by $B$. Sumantri. Jakarta: PT. Scholastic Press.

Wan C, Li Y., 2012. Fungal pretreatment of lignocellulosic biomass. Biotechnol Adv. ;30(6):1447-57.

$\mathrm{Xu}$, J., Cui, W., Cheng, J.J., and Stomp, A.M., 2011. Production of High-Starch
Science., 69(11): 1835-1844. DOI: https://doi.org/10.3382/ps.0691835.

Hensing, M.C.M., Rouwenhorst, R.J., Heijnen, J.J., Van Dijken, J.P. and Pronk, J.T., 1995. Physiological and technological aspects of large-scale heterologousprotein production with yeasts. Antonie van Leeuwenhoek., 67(3): 261-279.

Parisutham, V., Kim, T. H., and Lee, S. K. (2014). "Feasibilities of consolidated bioprocessing microbes: from pretreatment to biofuel production," Bioresource Technology 161, 431-440. DOI: 10.1016/j.biortech.2014.03.114.

Setiyatwan, H., 2007. Quality Improvement of Duckweed Nutrition through Fermentation using Trichoderma harzianum. Journal of Animal Science Padjadjaran University., 7.

Duckweed and Its Conversion to Bioethanol. Biosystems Engineering 110 (2), 67-72.

Zhao X., Moates G. K., Wellner N., Collins S. R A., Coleman M. J., and Waldron K. W., 2014. Chemical Characterisation and Analysis of the Cell Wall Polysaccharides of Duckweed (Lemna Minor). Carbohydrate Polymers 111, 410-18. 